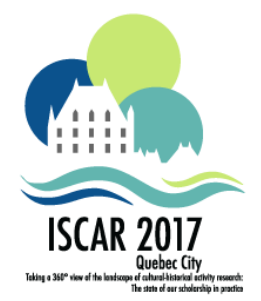

\title{
Multidimensional Model of the ZPD as Tool of Analysis of the Child's Cognitive-Personal Dynamics of Development While Overcoming Learning Difficulties
}

Irina Nikolaevskaya

HAVE_A_NIFE@MAIL.RU

Moscow State University of Psychology and Education

Moscow, Russia

\begin{abstract}
The main idea of the paper is based on L. S. Vygotsky's concepts of ZPD and collaboration of teacher and student. The special process between teacher and student, organised in child's zone of proximal development with using reflection and reflective questions as mail helping tools, leads to qualitative changes firstly in cognitive development of the student. Successes in learning activity create base for development of personal features. Thus, in such process, we may see strong connections between cognitive and personal developmental trajectories. Understanding of these connections gives an opportunity of mediative work with personal difficulties of a child, opportunity to turn simple processes of learning into counseling work, effecting all spheres of development.
\end{abstract}

Keywords : L. S. Vygotsky; ZPD; Collaboration between teacher and student; Tools. 
In the past two decades, the problem of the personal well-being of students has become more urgent. Technological progress provides virtually unlimited access to Internet resources, the flow of information, actually knocking children off their feet. Unfortunately, this is combined with obvious difficulties in the process of education, because many parents are primarily concerned about the financial well-being of their family. There are behavioral disorders, affective disorders, social comparisons, low self-esteem, etc. In parallel with this learning difficulties are widespread: low learning motivation, lack of meaning in learning activity, low scores and poor relations with teachers. The request for counseling of a psychologist can be both learning difficulties and personal problems. However, these problems are often combined.

This link of learning and personal difficulties reflects the described L. S. Vygotsky principle of unity of intelligence and affect. These two aspects of the psyche are interrelated and influence each other (Vygotsky, 1984). Based on this provision, it is possible to build advisory psychological and pedagogical help, involving both cognitive and personal developmental dimensions of the child. Such work is also possible to build using the principle of the connection between learning and development (Vygotsky, 1984). Learning leads child development. The cooperation of the adult and the child allows the child to develop, to appropriate new cultural means, and to use them in future in all spheres of life. Such cooperation is most productive within the zone of the proximal development.

In the work "The problem of age" L. S. Vygotsky introduces the concept of a zone of proximal development, characterizing it as an area in which a child is able to move with the help of an adult. This area is located between the zone of actual development, where the child can act independently, and a zone that is actually inaccessible, where even with the help of an adult, it is not possible for a child to successfully accomplish the task. The concept of a zone of proximal development reflects the collaboration of an adult and a child within the framework of joint activity. Also, it shows the actual level of development of the child, or rather the entire range of development trajectories, and, as L. S. Vygotsky wrote, the zone of proximal development can be applied to the description not only of learning activity, but also to the personal development of the child. Thus, the definition of the zone of the child's proximal development can serve as a diagnostic tool in determining cognitive and personal development (Vygotsky, 1984). This diagnostic tool is able not only to reflect the cognitive and personal development of the child, but also describe the relationship between cognitive and personal characteristics of development.

In certain situations, it is possible to initiate a child's personal development through the provision of psychological and pedagogical help. For a such connection, special conditions for the provision of psychological and pedagogical help are required, and these conditions are reflected in the principles and technologies of the reflective-activity approach (Zaretskii \& Gordon, 2011). The approach realizes in its practice a number of principles of culturalhistorical psychology, including the thesis "learning leads to development" (Vygotsky, 1984). The process of overcoming learning difficulties is carried out in the zone of the child's proximal development, that is, if a student has some difficulty in the learning process, then he has moved beyond the boundaries of his zone of actual development, and he needs the 
help of an adult. As the adult helps the child, both they are united by a common activity and are in collaboration. Under such conditions, dynamics of development arise.

There is an idea about the zone of the proximal development as a reflection of the dynamics of the child's cognitive and personal development. Also, there is an idea of the connection between problems of personal development and learning difficulties. It is assumed that due to this relationship, pedagogical help in overcoming learning difficulties under certain conditions can initiate positive dynamics of personal development (Kholmogorova \& Zaretskii, 2011; Zaretskii, 2016). For its verification, it is necessary to develop a method that allows recording the relationship between personal problems and learning difficulties, and the positive dynamics of personal development in providing the child with psychological and pedagogical help in overcoming learning difficulties.

The idea of multidimensional model of ZPD developed in reflective-activity approach is based on L. S. Vygotsky's concept of ZPD (Zaretskii, 2007, 2009). The model is a set of dimensions - the directions of development of various abilities of the child. Each dimension reflects the development of some abilities of the child in the process of carrying out his activity. Development is due to a qualitative transformation of these abilities. Owing to collaboration with an adult, the child internalizes new ways of activity, from the interpsychic they become intrapsychic, enriching the child's abilities, and this is reflected in the expansion of the zone of proximal development on each of the dimensions. Often, within the framework of one activity, dimension-resources and dimensions containing key difficulties for development at this stage. One of the tasks of counseling is helping the child overcome the key difficulty by activating, and developing all available resources for the child. Quite often, the key difficulties arise precisely on personal dimensions, so that direct work with them can be realized only in the form of psychotherapy, which is quite difficult in the work with children. However, working with learning difficulties becomes, in a certain sense, a metaphor for dealing with personal difficulties. The child creates characteristic ways of coping, which can be realized both in learning activity and in a broader life context, and overcomes personal difficulties indirectly through learning activity. In the process of overcoming the learning difficulties, all possible resources of the child, necessary to solve the problem, are actualized and initiated. To overcome the learning difficulties, it is necessary not only to be able to solve specific problems, but it is much more important to be able to overcome fear and learned helplessness, to take an agency position in relation to this difficulty, to analyze method of solution that does not lead to the correct answer, etc. Thus, resources are not initiated only the cognitive sphere, but also personal. For convenience, let us illustrate this example with the following scheme:

This model allows to determine the main learning difficulty and build the child development dimensions that are involved in the process of overcoming this learning difficulty. The main direction remains learning activity. It presents dimensions directly related to the learning difficulty, but also reflects other development trajectories that belong to different spheres, including the sphere of personal development. Thus, the construction of a multidimensional model of the child's zone of proximal development makes it possible to record the development dimensions involved in this learning activity, which are resources, 


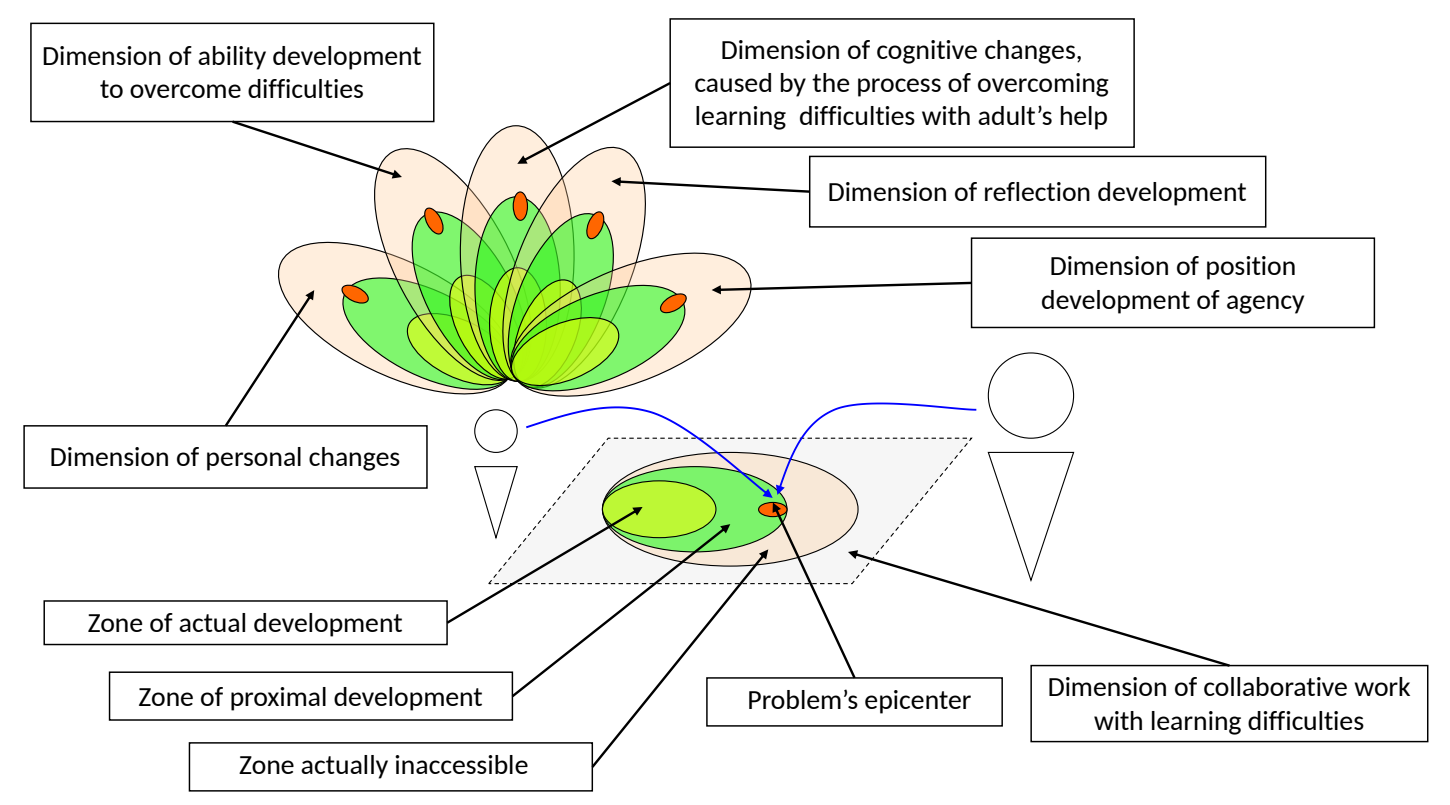

Figure 1. Scheme of the zone of proximal development as a set of dimensions in which "steps" in development are possible (Zaretskii, 2013).

tightened by a problem epicenter. An analysis of the dynamics of development on these dimensions makes it possible to make assumptions about possible connections between them. The definition of an epicenter problem makes it possible to build counseling activity aimed at the initiation and development of child resources.

Learning activity becomes a space in which the child's collaboration with an adult is linked to overcoming the learning difficulties and problems of the child in the personal sphere. In the process of working together, the child opens up new resources to overcome learning difficulties, and these same resources are used by him to overcome personal difficulties.

Thus, we can distinguish several basic stages of the method of analysis. At first, we record the initial learning difficulty. Then, the analysis of joint activity aimed at overcoming this difficulty allows to determine the internal obstacles and resources that shape the situation. A general picture reflects the present dimensions and their relationship to each other. The help process is recorded each session, which allows to track the overall and particular dynamics of changes, as well as to trace the relationship between the help provided and cognitive-personal changes.

This conceptualization is most productive when dealing with "difficult" cases. We conducted a qualitative study of the cases of overcoming the student's learning difficulties. As an example of the analysis of the dynamics of cognitive-personal development using the multidimensional model of the zone of proximal development, we will cite the case of work with one of the students, Nastya. At the beginning of the work, Nastya was 13 
years old, at the end of the school year she was not certified for two subjects. The overall picture was rather sad, because Nastya was absolutely passive, afraid of assignments, did not want to overcome difficulties, did not want to think about her difficulties and think about herself as an active person in principle. Her mother was making most of Nastya homework's, a tradition that had arisen in this family several years ago, so the Nastya's ability to work independently literally atrophied. In addition to such a family and personal picture, Nastya also had cognitive difficulties: the viscosity of thinking, the low level of generalization, the impossibility of working in the ideal plane, and the high fatigue. By some indications, it was possible to determine an easy degree of mental retardation.

At the beginning of the work, the first dimensions were defined: reflection, the ability to solve the task in the mind, the ability to solve the task in the material plane - the basic cognitive dimensions, here they are presented in a complex form. Personal dimensions: agency position in relation to learning activity, subjectivity, idea of own activity, selfdetermination, attitude to difficulties. Personal dimensions are related to each other, reflect Nastya's idea of herself as an active subject of her own activity. In this case, personal dimensions are linked with cognitive ones. The agency position in relation to learning activity is connected with the dimension of reflection, because it is impossible to reflect the methods of one's activity, to modify these methods without showing the activity and awareness that are inherent in the subject of this activity. Initiation of development in these related dimensions makes it possible to analyze ways of solving problems, modify unproductive methods or choose the most convenient ones. Also, the dimension of selfdetermination is linked to more general context with all cognitive dimensions, because it allows the child to initiate self-development. Development in the dimension of attitude to the difficulty allows us to perceive difficulties and mistakes not as insurmountable obstacles, but as situational problems that can be solved with some efforts, that supports the development of the concept of activity on the dimension of the activity, helping to retain meaning, and also helps constructively plan its own work with methods.

These dimensions were highlighted after two sessions with Nastya, on the base of the diagnostic work, its joint analysis and reflection of mistakes. This allowed us to determine the zone of actual development - what Nastya can do on her own, as well as the difficulties that she cannot overcome by herself, but she is able to do this together with an adult. Also, from the reflection of Nastya, was received information about her attitude to difficulties, about ways of solving mathematical problems, about the general attitude to mathematics and education.

As a result of diagnostics on the dimensions of the model, a key problem was identified - the lack of seeing herself as the subject of her own activity - it pulled together several personal dimensions - self-determination, the idea of own activity, subjectivity. These are abilities of a person that allow her to recognize herself as an active subject of her own life, which means that Nastya practically did not feel herself the master of her life, everything was performed for her by adults, she did not have the opportunity to choose or make selfdetermination, in fact she was the executor of other's plans and instructions. As a result, there is a lack of agency position in relation to learning activity and, as a result, an almost 
complete lack of ability to reflect. The agency position cannot arise in conditions when practically all decisions are taken for the child by adults, when the child is not a subject of his own activity. Reflection is also not initiated, because there is no need to analyze methods of activity. When Nastya encountered a mistake, she did not analyze her possible reasons and the way she came to this mistake, most often her mistake was corrected by adults. In addition, Nastya was able to implement the simplest tasks only in the material plane and almost completely could not transfer these tasks to the ideal plane.

One of the ideas of the consultant's work was to help Nastya learn to overcome her learning difficulties on her own. This is possible only if Nastya is able to feel herself the subject of her activity, to understand why she needs this activity, and to learn how to reflect on her methods of activity. A direct conversation about Nastya's desires, her ideas about the future and her personal meaning in math was not successful. Nastya really tried, but she could not answer to these questions. Therefore, there was an idea to come to this through learning activity. One of the intermediate results was the initialization of Nastya's ability to reflect on her methods of activity and choose from them the most convenient for her personally. For this, it was decided to initialize the development of the dimension "the ability to solve the problem in the mind", because it would allow Nastya to use those cognitive resources that will allow to move as far as possible from the mechanical unconscious performance of the task and begin to analyze her methods of activity.

Several lessons were spent on elementary teaching to the simplest abstract representations - the categories of the number. Learnt to understand numbers as complex abstract objects, and not as a linear record of numbers, Nastya began to try to count in her mind. Basically, these were examples of addition and subtraction of two-digit numbers, she fairly confidently applied the method of "convenient" addition or subtraction, first working with tens, and then with units. When this method was mastered by her, the moment $X$ came. The consultant suggested to Nastya how she likes to solve math tasks, in her mind or in a notebook, writing down a column. Getting the right answer when solving the task in the mind brought Nastya great pleasure. She felt this as her own personal achievement. So, after a short hesitation, she chose the method of solution in her mind.

At this point, several steps have been taken on several personal development dimensions. On the dimension of subjectivity, the ability to feel herself active in her life, to be able to think and choose, to abandon something on the basis of her own thoughts arose. On the dimension of the agency position in relation to learning activity, there emerged the realization that this learning activity is just her, and she is a subject in it. On the dimension of the idea of own activity, it was possible to plan activity in accordance with her own desire to realize something. On the dimension of attitude to the difficulty, several steps were realized - increasing self-confidence, there was an idea of the difficulty as something that can be handled, the difficulties began to be perceived not as something fatal, but as points on a further path of overcoming.

The intermediate dimension in this work was the ability to reflect, due to the initiation and development of this ability Nastya, in principle, had the ability to look at herself, her activity and the ways of her activity from outside. 
This dynamic was achieved in the first seven sessions. All classes were built in accordance with the principles of the reflective-activity approach. Each lesson began with a discussion of the general idea for the current lesson. The learning activity was organized together, each session ended in reflection - a discussion of the difficulties, successes, and the specifics of the help provided.

The fixation of the process and the results of each lesson allows us to correlate these results with each other, to observe the dynamics of cognitive development and progress in personal development. The picture was most voluminously reflected using a multidimensional model of the zone of proximal development. Each new appropriated cultural tool is a step on one of the dimensions of development, which opens up opportunities for development on other related dimensions. This case of practice is a brief illustration of the possibility of using the multidimensional model of the zone of proximal development as a tool for diagnosing and analyzing the dynamics of the child's cognitive and personal development in the process of overcoming learning difficulties.

\section{References}

Kholmogorova, A. B., \& Zaretskii, V. K. (2011). Mozhet li kul'turno-istoricheskaya kontseptsiya L. S. Vygotskogo pomoch' nam luchshe ponyat', chto my delaem kak psikhoterapevty [Can the cultural-historical psychology of Vygotsky help us better understand what we are doing as psychotherapists]. Kul'turno-istoricheskaya psikhologiya [Culturalhistorical psychology](1), 108-118.

Vygotsky, L. S. (1984). Problemy detskoi (vozrastnoi psikhologii) [Problems of childhood (developmental) psychology]. In Collected works in 6 volumes. Vol. 4. (p. 243-432). Moscow: Pedagogika.

Zaretskii, V. K. (2007). O chem ne uspel napisat' L. S.Vygotskii [What Vygotsky didn't have time to write]. Kul'turno-istoricheskaya psikhologiya [Cultural-historical psychology](3), 96-104.

Zaretskii, V. K. (2009). Zone of proximal development: What Vygotsky didn't have time to write. Journal of Russian and East European Psychology, 47(6), 70-93.

Zaretskii, V. K. (2013). Stanovlenie i sushchnost' refleksivno deyatel'nostnogo podkhoda v okazanii konsul'tativnoi psikhologopedagogicheskoi pomoshchi [Development and nature of Reflection and Activity Approach to the provision of advisory psychological and educational assistance]. Konsul'tationaya psikhologiya i psikhoterapiya [Counseling psychology and psychotherapy](2), 8-37.

Zaretskii, V. K. (2016). Odin shag v obuchenii - sto shagov v razvitii: Ot idei k praktike [Vygotsky's Principle "One step in learning - One hundred steps in development": From idea to practice]. Kul'turno-istoricheskaya psikhologiya [Cultural-Historical Psychology], 12(3), 149-188.

Zaretskii, V. K., \& Gordon, M. M. (2011). O vozmozhnosti individualizatsii obrazovatel'nogo protsessa na osnove refleksivno-deyatel'nostnogo podkhoda v inklyuzivnoi praktike [Possibility of individualization of the educational process on the basis of reflection and activity approach in the inclusive practice]. Psikhologicheskaya nauka $i$ obrazovanie [Psychology science and education](3), 19-26. 